\title{
桐材の難燃性とそのメカニズムに関する研究 \\ A Study on Flame Retardency of Paulownia Wood and the Mechanism
}

\author{
O正 李 鵬（金沢大） 正 尾田 十八（金沢大）
}

Peng LI, Kanazawa University, Venture Business Laboratory, Kakuma, Kanazawa, Ishikawa Juhachi ODA, Kanazawa University

Key Words: Paulownia wood, Flame retardency, Mechanism, Structure, Cedar wood

\section{1. はじめに}

桐 (Paulownia) は落葉小高木で, 成長が極めて速く, 通常 $15 \sim 20$ 年で高さ $10 \mathrm{~m}$, 直径 $50 \mathrm{~cm}$ くらいまでになる. その特 性は，軽く、柔らかく、狂いが少ない，また防虫、調湿、 断熱などの性能も優れている. このようなことから，古く から箪笥や各種調度品としてよく使用されてきている. 火 事で桐箪笥が真っ黒になっても, 中の着物が無事であった とのことは, よく知られている. そこで, 本研究ではまず 桐材の難燃性を実験的に確認し，次に，材料構造組織を考 察し，その難燃性のメカニズムがどのようなものであるの かを検討する. また，これと比較する材料として杉材につ いても同様な実験を行った.

\section{2. 桐材の難燃性}

2-1 熱伝導率の測定 JIS A1412 に規定されている平板 比較法による木材の熱伝導率測定方法を採用した(1). 一般 木材の熱伝導率は約 $0.06 \sim 0.2 \mathrm{kcal} / \mathrm{mh}^{\circ} \mathrm{C}$ である. 測定結果 では，実験用桐材の熱伝導率 $\lambda=0.089 \mathrm{kcal} / \mathrm{mh}^{\circ} \mathrm{C}$, 杉材 (Cedar)の熱伝導率 $\lambda=0.088 \mathrm{kcal} / \mathrm{mh}^{\circ} \mathrm{C}$, ほぼ同じであるが,

これらは木材の中でも低い方に属している.

2-2 板の加熱実験 Fig.1 のように，450Cに熱したアル ミ板の上に杉および桐の板 $(85 \mathrm{~mm} \times 85 \mathrm{~mm} \times 12 \mathrm{~mm})$ を載 せ各々の状況変化を観察する. 桐板を載せた後 1 分ほどで, $6 \mathrm{~mm}$ の炭化層が出来たが, 杉板は $2 \mathrm{~mm}$ の炭化層しかでき なかった. その後, 杉板の炭化層は進行しながら，30 分後 大部分が灰になってしまった，一方，桐板の炭化層はゆっ

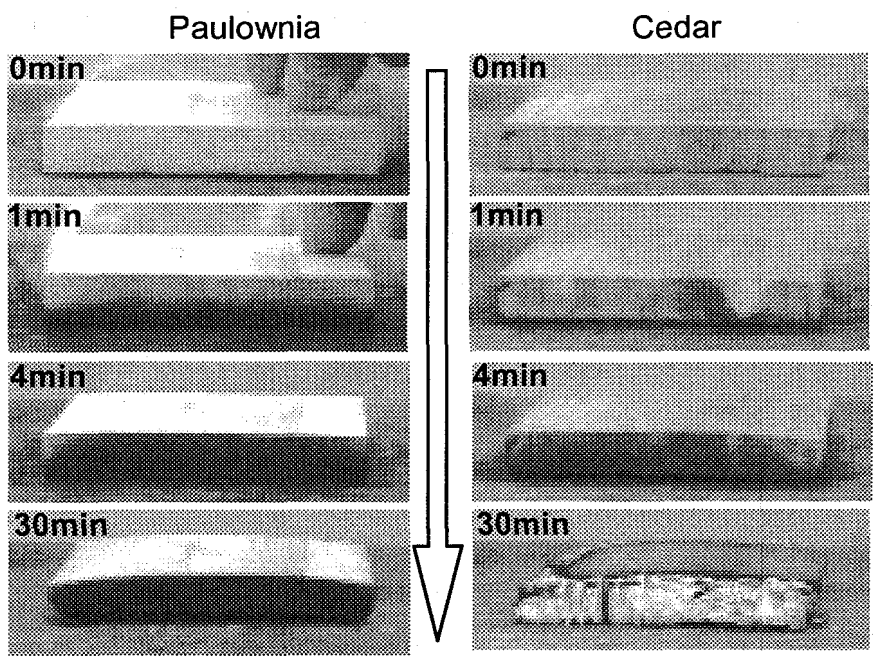

Fig.1 Appearance of heating wood board.
くり増大するが，灰にならない，すなわち，桐板は炭化し やすいが，炭化後炭化層が灰になるのは遅いということが 分った.

2-3 箱の加熱実験 桐箪笥を模擬して箱の加熱実験を行 つた. 板の加熱実験と同じように，アルミ板の上に桐箱と 杉箱を載せ電熱器によって温度を上げていく．そのときの 加熱面であるアルミ板と箱の内部温度を計測する．箱の内 容積はすべて $200 \mathrm{~mm} \times 200 \mathrm{~mm} \times 100 \mathrm{~mm}$ である，壁厚はそれぞ れ杉箱 $12 \mathrm{~mm}$ ，桐箱 $12 \mathrm{~mm}$ と $24 \mathrm{~mm}$. また，加熱面に $5 \mathrm{~m} \mid$ の水 分をスプレーで均一にかけた箱の加熱実験も行った． 結果 より次のことが言える.（1）桐材の方が杉材に比べ燃焼ま での時間が約 30 分長い. (2) 桐材の方は, 加熱時間 40 分 から 120 分までの間での温度上昇が緩やかになっている.

（3）水分をかけた杉箱の内部温度はあまり変わっていない が，桐箱の方は $20^{\circ} \mathrm{C}$ 低くなっている.（4）厚さ $24 \mathrm{~mm}$ の桐 箱内部温度が $12 \mathrm{~mm}$ のものより $50^{\circ} \mathrm{C}$ 低くなっている

\section{3. 桐材の構造組織}

桐材は散孔材的な傾向をもち環孔材で，髄心がとくに大 きい. 年輸は明瞭に認められ，材面の肌目はややあらい感 じである. 顕微鏡的な構成要素は導管, 木繊維, 柔組織と 放射組織である(2).Fig.2 の(a)と(b)には桐材および杉材の 横断面の SEM 写真を示す. 桐材導管の径は比較的大きく, 150〜350 $\mu \mathrm{m}$ である. 年輪のところに大きい導管がたくさ ん集まり，他の部分には小さめの導管が均一に分布してい
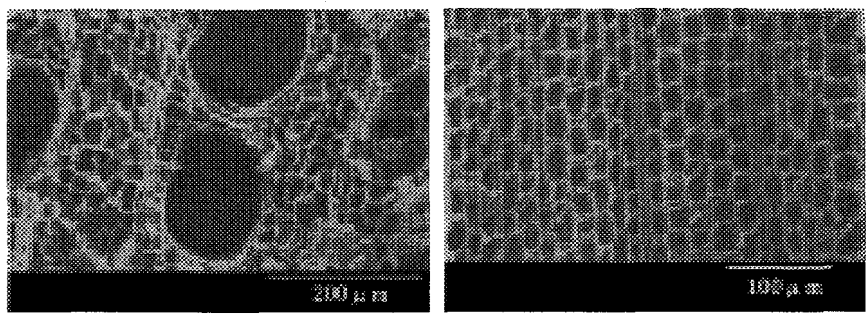

(a) Cross section of Paulownia (b) Cross section of Cedar
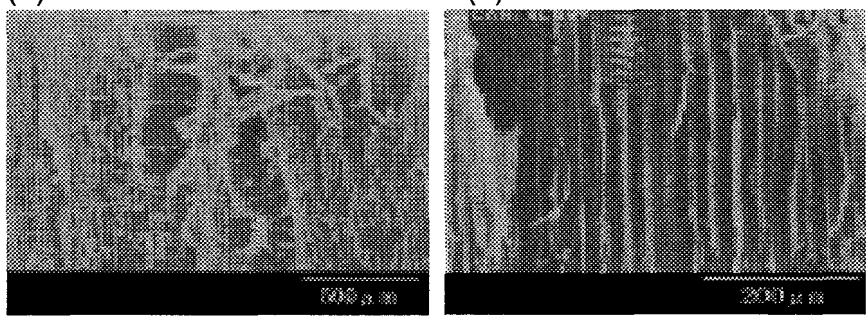

(c) Radial section of Paulownia (d) Radial section of Cedar Fig.2 SEM micrographys of the wood 
る. 木繊維は構成要素の $50 \%$ 近くを占め, 細胞は八ニカム 構造に近い, 径は約 25 45 $\mu \mathrm{m}$, 壁厚は非常に薄い, 約 1 $\mu \mathrm{m}$ である. 桐材全体の空陌率は約 $82 \%$ ある. 一方, 杉 材の横断面には仮導管が均一に分布され，径は約 $30 \sim 50$ $\mu \mathrm{m}$, 細胞壁がやや厚い, 約 $3 \mu \mathrm{m}$ である. 杉材全体の空 隙率は約 $72 \%$ あ゙る. Fig.2の(c)と(d)は桐材および杉材の 放射断面の SEM 写真である. 桐材の縦方向には，太い導 管が独立にあり，これに対して，杉材では仮導管は細いが 連続となっていることがわかる.

\section{4. 桐材の難燃性のメカニズム}

木材の燃焼条件は次の二つであることが知られている(3). (1)熱分解生成物と空気よりなる可燃性混合気層が発炎に 必要な濃度になること，(2)可燃性混合気層の発火に必要な エネルギーが供給されること．これまでの実験では，同じ 加熱条件であるので, 桐材の難燃性は主に条件(1)の影響で あると予測される。

Fig.3に桐材および杉材の燃焼時のガスのクロマトグラ フィー分析結果を示す．杉材では, アルカン類の成分がや や多いが，桐材にはフラン系と酢酸の量が多く見られた.

すなわち, これより杉材には若干のある可燃性ガス成分が 桐材より多いことが明らかとなった.

また，材料の化学組成分析結果を Table1 に示す. これよ り，桐材はリグニンの成分が杉材より $5 \%$ 少ない，リグニ ンが多いほど，発生熱量と発生ガス量が多いという報告が ある(4). 元素組成分析結果を Table2 に示す. 木材の構成元 素は主に炭素(C)，水素(H)，酸素(O)であり，炭素は $40 \%$ 以上占めている。

さらに, Fig.2(d)より杉材の仮導管が軸方向に連続してい るが、Fig.2(c)桐材の道管は太くて, 独立した構造となって いる. この構造から燃焼時桐材の内部まで酸素が流通しに くく，発炎に必要な濃度になりにくいと考えられるので， 次のような実験を行った。

木材の構造をまねて Fig.4 のようなダンボールでモデル を作り，加熱実験を行った. 杉モデル(縦 $80 \mathrm{~mm} \times$ 横 $160 \mathrm{~mm}$ ×奥 $200 \mathrm{~mm}$ ）は 16 枚のダンボール板を単に重ねて貼付け

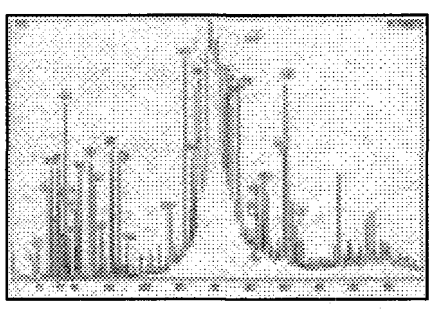

(a) Paulownia

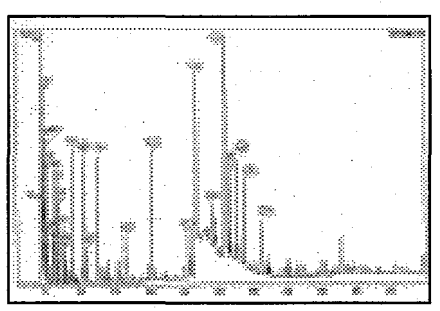

(b) Cedar
Fig.3 Gas chromatography analysis of heating the wood

Table1 The result of chemical composition analysis

\begin{tabular}{|c|c|c|c|}
\hline & Cellulose & Hemicellulose & Lignin \\
\hline Paulownia & $45 \%$ & $25 \%$ & $29 \%$ \\
\hline Cedar & $49 \%$ & $16 \%$ & $34 \%$ \\
\hline
\end{tabular}

Table2 The result of elementary composition analysis

\begin{tabular}{|c|c|c|c|}
\hline & $\mathrm{C}$ & $\mathrm{H}$ & $\mathrm{O}$ \\
\hline Paulownia & $43.76 \%$ & $5.81 \%$ & $50.43 \%$ \\
\hline Cedar & $47.98 \%$ & $6.03 \%$ & $45.99 \%$ \\
\hline
\end{tabular}

したもので，穴は完全に貫通状態である. 一方，桐モデル は杉モデルの奥行き方向を三等分に切り，さらにこの位置 にダンボール紙を縦に入れ粘着したものである。つまり穴 は独立している. 実験方法は 2-2 の板の加熱実験と同様で ある. 加熱条件は室温から温度を徐々に上げ， 70 分後

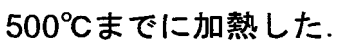

Fig.5には加熱から 70 分後の両モデルの様子を示す. 実 験結果から，同一条件下で加熱した場合，杉モデルは桐モ デルよりよく燃焼していることがわかる．桐モデルの 70 分間の燃焼様子は杉モデルの 50 分間の様子に相当する. すなわち，桐のような独立した空孔構造が貫通穴構造より 燃焼の遅いことが明らかとなった。

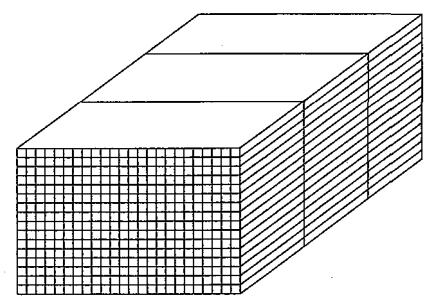

(a) Model of Paulownia

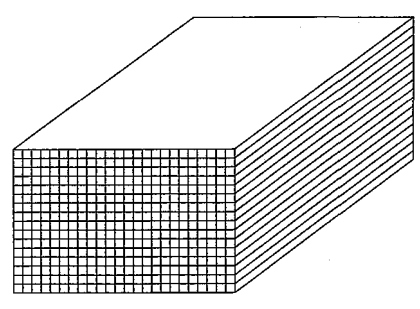

(b) Model of Cedar
Fig. 4 The model of wood made of corrugated paper

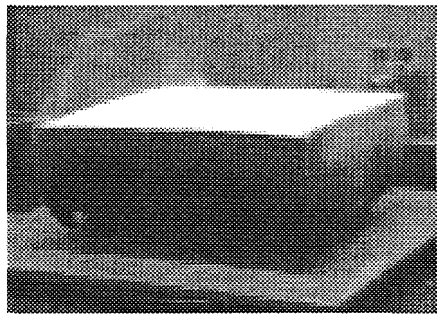

(a) Model of Paulownia

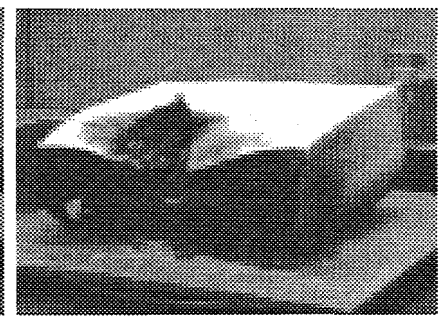

(b) Model of Cedar
Fig. 5 The result of heating the model

\section{5.考察}

桐材は細胞組織がハニカム構造のように非常にポーラス 状で密度が低い，熱を受けると炭化しやすい，また桐材の リグニン成分がやや少ないので，加熱時に発生する可燃性 ガスが少ない，さらに独立である導管構造で各部に酸素が 供給しにくいので発火しにくく炭化のみが進行すると考え られる.この炭化層は一般にその母材の熱伝導率より低い. 従って，桐箱内の温度は上昇しにくくなると考えられる。

\section{6. おわりに}

桐材の熱伝導率や燃焼実験を通して，桐材の炭化しやす くかつ発火しにくい性質を実験的に確認した。 また，材料 構造および成分の考察とモデル燃焼実験により，桐材の難 燃性のメカニズムを知ることが出来た．今後これらの結果 を新しい難燃性材や不燃性材料の開発に結びつける研究を 進める所存である.

\section{参考文献}

(1) 日本木材学会編，木材科学実験畫，p149.

(2) 平井信二, 木の事典, 1980 , 第 1 集第 5 巻.

(3) 原田寿朗, 森林総合研究所研究報告, 378, 2000, p1.

(4) 岡村敏章, 高知工科大学大学院工学研究科平成 16 年度 修士学位論文, 2005. 